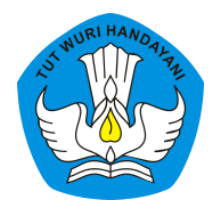

Page: 193-208

\title{
Upaya Meningkatkan Hasil Belajar Siswa \\ pada Pembelajaran Membuat Poster melalui Pendekatan Keterampilan Proses Berbasis Android
}

\author{
Fitri Gurnitasari \\ Sekolah Menengah Pertama Negeri 3 Tasikmalaya, Jawa Barat \\ ${ }^{1}$ Contributor Email: gurnitasari.fitri@gmail.com
}

Published: Mar 30, 2020

Article Url: http:/ / ojsdikdas.kemdikbud.go.id/index.php/didaktika/article/view/156

\begin{abstract}
This study aims to describe efforts to improve student learning outcomes in learning to make posters through an Android-based process skill approach. With the Classroom Action Research (CAR) method it has been proven that through the Android-based process skills approach to learning to make posters can improve the learning process, student activities and student learning outcomes which are characterized by an increase in student learning processes from an average score of 2 (50\%) categories enough in pre-action, it became 3 (75\%) good categories in cycle 1 (increased by 25\%), and increased in cycle 2 to 3.2 (80\%) with very good categories (increased by 5\%). Secondly, the increase in student learning activities from an average score of $3(60 \%)$ is sufficient in the pre-action category, to $4(80 \%)$ in the high category in cycle 1 (increased by 20\%) and progressively increases in cycle 2 by increasing the average score to $4.4(87 \%$ ) the category is very high (an increase of $7 \%)$. Third, the increase in student learning outcomes on average $82(25 \%)$ in preaction to $85(75 \%)$ in cycle 1 (increased 50\%) and increased in cycle 2 to $88(90 \%)$. Based on the analysis of practical applications it can be concluded that the approach of the Android-based process skills can improve student learning outcomes in learning to make posters.
\end{abstract}

Keywords: Learning Outcomes, Poster, Process Skill Approach, Android 


\begin{abstract}
Abstrak
Penelitian ini bertujuan mendeskripsikan upaya meningkatkan hasi belajar siswa pada pembelajaran membuat poster melalui pendekatan keterampilan proses berbasis android. Dengan metode Penelitian Tindakan Kelas (PTK) telah dibuktikan bahwa pendekatan keterampilan proses berbasis android pada pembelajaran membuat poster dapat meningkatkan proses pembelajaran, aktivitas siswa, dan hasil belajar siswa yangditandai dengan meningkatnya proses pembelajaran siswa dari rata-rata skor 2 (50\%) katagori cukup pada pra tindakan, menjadi 3 (75\%) katagori baik pada siklus 1 (meningkat 25\%), dan semakin meningkat pada siklus 2 menjadi 3,2 (80\%) dengan katagori amat baik (meningkat 5\%). Kedua, meningkatnya aktivitas pembelajaran siswa dari rata-rata skor 3 (60\%) katagori cukup pada pra tindakan, menjadi 4 (80\%) katagori tinggi pada siklus 1 (meningkat 20\%) dan semakin meningkat pada siklus 2 dengan peningkatan rata-rata skor menjadi 4,4 (87\%) katagori sangat tinggi (meningkat 7\%). Ketiga, meningkatnya hasil belajar siswa rata-rata 82 (25\%) pada pra tindakan menjadi 85 (75\%) pada siklus 1 (meningkat 50\%) dan semakin meningkat pada siklus 2 menjadi 88 (90\%). Berdasarkan analisis aplikasi praktis dapat disimpulkan bahwa pendekatan keterampilan proses berbasis android dapat meningkatkan hasil belajar siswa pada pembelajaran membuat poster.
\end{abstract}

Kata Kunci: Hasil Belajar, Poster, Pendekatan Keterampilan Proses, Android

\title{
A. Pendahuluan
}

Pada pembelajaran seni rupa kelas VIII semester 4, Kompetensi Dasar (KD) 3.3. adalah memahami konsep, syarat, alat, dan bahan poster dan KD 4.1. membuat poster, diharapkan hasil belajar siswa mencapai Kriteria Belajar Minimal (KBM) sebesar 80. KBM ini harus tergambar pada poster karya siswa dengan indikator topik/tujuan bervariasi, kalimat menarik/ komunikatif, gambar menarik serta menggunakan media sesuai perkembangan ilmu pengetahuan dan teknologi. Namun, kenyataannya hasil pembelajaran siswa pada KD di atas belum memenuhi KBM, terlihat pada pengamatan awal yang dilakukan penulis Senin 11 Februari 2019 terhadap 31 siswa VIII G SMPN 3 Tasikmalaya Jawa Baratterdapat 8 siswa (25\%) yang memilih topik/ tujuan beragam, kalimat yang menarik/ komunikatif, gambar menarik, namun belum memanfaatkan teknologi imformatika (memenuhi KBM 80). Sisanya, 23 siswa (75\%) masih 
menggunakan topik/tujuan yang tidak variatif, kalimat kurang memarik/ tidak komunikatif, gambar sederhana dan media terbatas/belum memanfaatkan teknologi imformatika.

Hal tersebut terjadi diantaranya karena pendekatan pembelajaran yang digunakan belum tepat. Guru belum berupaya secara maksimal untuk menciptakan proses pembelajaran sesuai harapan Permendikbud tentang standar proses dan tantangan abad 21. Pendekatan pembelajaran yang digunakan guru pada pembelajaran membuat poster masih konvensional yaitu dengan cara membebaskan siswa memilih topik/tujuan poster, membebaskan siswa memilih kalimat poster, membebaskan siswa menentukan gambar serta media, sehingga kurang merangsang kreativitas siswa dalam berkarya poster. Siswa cenderung kebingungan menentukan tema/judul, kebingungan memilih kalimat serta menentukan gambar dan cenderung menggunakan media apa adanya.

Pendekatan ini hanya membuat beberapa siswa saja dapat berkreativitas membuat poster dengan variatif. Sisanya sebagian besar siswa memaknai kebebasan tersebut dengan anggapan dapat berkarya apa saja bebas, termasuk membuat poster dengan gambar yang sudah pernah digambar sebelumnya oleh siswa tersebut/ tidak ada ide baru. Kalimat dan gambar yang digunakan siswa pada poster juga tidak menunjukkan kebaruan dan kurang menarik, termasuk media yang digunakan terkesan apa adanya.Hal ini menyebabkan sebagian besar siswa tidak mencapai KBM.

Latar belakang masalah diatas, mendorong penulis untuk melakukan penelitian/inovasi pembelajaran membuat poster melalui pendekatan keterampilan proses berbasis android. Melalui pendekatan ini akan tercipta proses pembelajaran yang diharapkan/ sesuai Permendikbud No 22 Tahun 2016 tentang Standar Proses yang nota bene akan meningkatkan hasil belajar siswa. Disamping itu, pendekatan inidapat memediasi siswa memiliki kemampuan berpikir kreatif, kritis, 
komunikatif dan kolaboratif sebagai dasar untuk mempersiapkan siswa menyambut Era Revolusi Industri 4.0.

Berdasarkan paparan di atas, penelitian ini dilakukan penulis bertujuan untukmendeskripsikan upaya meningkatkan hasil belajar siswa pada pembelajaran membuat poster melalui pendekatan keterampilan proses berbasis android. Keberhasilan proses, aktivitas dan hasi belajar diantaranya dipengaruhi oleh kompetensi guru dalam merancang, memilih, menentukan, dan menggunakan pendekatan pembelajaran. Hasil belajar adalah sesuatu yang diadakan (dibuat, dijadikan) oleh usaha dalam memperoleh kepandaian ilmu (KBBI.2005:391).

Beberapa ahli berpendapat tentang hasil belajar, diantaranya Sujana, hasil belajar yaitu kompetensi yang diperoleh siswa setelah proses pembelajaran, Suprijono berpendapat bahwa hasil belajar merupakan perbuatan, value, wawasan, karakter apresiasi dan skil, sedangkan Nana Sujana berpendapat bahwa hasil belajar adalah perubahan kognitif, afektif dan psikomotor (https://www.dosenpendidikan.com). Hasil belajar yang baik merupakan domain yang ingin dicapai oleh guru dan siswa (Raba.2017:58). Dengan demikian, dapat disimpulkan bahwa hasil belajar adalah tujuan yang ingin dicapai guru dan siswa dengan baik berupa perubahan afektif, kognitif, dan psikomotor siswa setelah mengalami proses belajar yang diukur melalui kegiatan evaluasi. Hasil belajar sebagai salah satu indikator pencapaian tujuan pembelajaran di kelas dipengaruhi oleh faktor internal dan eksternal (https/ / eprints.uny.ac.id/982902/0002.pdf).

Pada penelitian/inovasi pembelajaran ini penulis memanfaatkan faktor eksternal siswa berupa penggunaan pendekatan keterampilan proses berbasis android untuk meningkatkan hasil belajar siswa. Adapun hasil belajar siswa yang akan ditingkatkan yaitu hasil belajar membuat poster yang akan diukur melalui penilaian proses dan hasil.

Poster adalah sebuah karya seni rupa yang memuat komposisi huruf dan gambar, dibuat dalam berbagai ukuran, berfungsi untuk menyampaikan pesan secara singkat (Purnomo, dkk.2017:124-125). Pada 
penelitian/ inovasi pembelajaran ini topik atau tujuan poster yaitu 8 nilai karakter bangsa terdiri dari nilai religius, jujur, peduli sosial, peduli lingkungan, gemar membaca, cinta tanah air, kreatif, dan disiplin. Delapan tema ini diterjemahkan siswa ke dalam berbagai judul poster yang relevan, dengan catatan judul poster antara siswa satu dengan lainnya berbeda, sehingga di kelas tersebut dihasilkan poster dengan jumlah judul sebanyak siswa di kelas tersebut. Kalimat yang digunakan pada poster menggunakan kalimat singkat, mudah diingat, menarik, sesuai topik/ tujuan/ judul.

Gambar utama pada poster dalah foto selfie siswa yang diedit dengan menambahkan kalimat menyesuaikan pada topik/ tujuan/ judul poster, dengan memperhatikan unsur-unsur seni rupa (titik, garis, bidang, bentuk, tekstur, gelap terang, warna) serta prinsip-prinsip seni rupa (keseimbangangn, proporsi, komposisi, irama, kestuan, pusat perhatian). Adapun media yang digunakan adalah $h p$ android dengan aplikasi edit foto diantaranya canva, inshot, dan picsart.

Setiap proses pembelajaran tidak terlepas dari pemilihan yang tepat terhadap model, pendekatan, strategi, metode, dan teknik pembelajaran agar proses pembelajaran berjalan lancar dan memudahkan dalam pencapaian tujuan pembelajaran. Pendekatan keterampilan proses pada hakikatnya adalah suatu pengelolaan kegiatan belajar-mengajar yang berfokus pada pelibatan murid secara aktif dan kreatif dalam proses pemerolehan hasilbelajar (Conny,1992). https:/ / www.rijal09.com/2016/0 4/pengertianpendekatan-proses-pendekatan.html.

Berdasarkan penjelasan tersebut dapat dipastikan bahwa pemilihan/ penentuan pendekatan pembelajaran dalam suatu proses pembelajaran merupakan salah satu hal penting yang dapat menentukan keberhasilan belajar siswa.Pemilihan pendekatan pembelajaran yang tepat menjadi tolak awal bagi guru dalam menciptakan pembelajaran yang dapat merangsang berfikir kreatif siswa (Khuana dan Khuanai. 2017:286). Merencanakan suatu pendekatan pembelajaran dengan baik dapat 
membantu siswa dalam proses pembentukan kemampuan berfikir kreatif, kritis, komunikatif dan kolaboratif yang diperlukan siswa dalam menyikapi tantangan pendidikan abad 21.

Dengan demikian, penulis dalam karya inovasi pembelajaran ini merancang suatu pendekatan pembelajaran dengan memanfaatkan kesenangan siswa berselfy dan mengedit foto selfy menjadi suatu pendekatan keterampilan proses yang memperhatikan pengembangan pendidikan karakter, literasi, inovatif, membangkitkan antusiasisme siswa serta memanfaatkan teknologi imformatika bebasis android. Proses pembelajaran membuat poster melalui pendekatan ini menyenangkan siswa, aktivitas siswa meningkat karena siswa merasa sedang bermainmain dengan HP-nya, sehingga pembelajaran menjadi efektif dan pada akhirnya hasil belajar siswa menjadi meningkat. Dampak positif dari penggunaan strategi pembelajaran yang cocok dengan materi pembelajaran, sesuai dengan perkembangan jaman, menarik minat dan melibatkan peran aktif siswa dapat menciptakan efektifitas dan efisiensi proses pembelajaran yang pada akhirnya akan mempercepat/ meningkatkan hasil belajar siswa (Raba.2017:58).

Pendekatan ini cocok dengan KD yang akan dipelajari, sesuai dengan perkembangan jaman, menarik minat siswa, melibatkan peran aktif siswa, menciptakan proses pembelajaran yang efekif dan efisien. Pada penelitian/ inovasi pembelajaran ini, telepon genggam/ hp yang digunakan siswa pada pembelajaran membuat poster adalah hp android, karena hampir semua siswa di kelas VIII G SMPN 3 Tasikmalaya memiliki dan terbiasa menggunakan hp android dalam kehidupan sehariharinya. Selain itu hp android memiliki banyak aplikasi edit foto praktis seperti canva, inshot, picsart dsb, yang biasa digunakan siswa untuk mengedit foto. Hal ini dimanfaatkan penulis untuk meningkatkan hasil belajar siswa dalam pembelajaran membuat poster melalui pengembangkan kemampuan edit foto selfie yang sudah dimiliki siswa menjadi poster dengan menambah kalimat, gambar sesuai topik/tema 
yang sudah ditentukan dengan memperhatikan unsur-unsur seni rupa (titik, garis, bidang, bentuk, tekstur, gelap terang, warna) serta prinsipprinsip seni rupa (keseimbangan, proporsi, komposisi, kesatuan, irama, pusat perhatian).

\section{B. Metode}

Proses penemuan pendekatan proses berbasis android yaitu melalui Penelitian Tindakan Kelas (Classroom Action Research) dalam 2 siklus, masing-masing siklus terdiri dari 4 tahapan yaitu perencanaan (plan), pelaksanaan (action), pengamatan dan penilaian (observation)serta refleksi(reflection).

Pada siklus 1, hal yang dipersiapkan di tahap perencanaan adalahRPP perbaikan, yaitu RPP KD 3.3. Memahami Konsep, Syarat, Alat dan Bahan Poster dan KD 4.3. Membuat Poster, dan pada RPP ini diterapkan pendekatan ketrerampilan proses berbasis Android, materi dan presentasi membuat poster menggunakan power point, media pembelajaran berupa laptop, proyektor/infocus, printer dan HP (Hand Phone) android, alat pelajaran berupa solatif, gunting, dan kertas, menyiapkan daftar hadir dan daftar nilai siswa, daftar pertanyaan untuk wawancara, lembar observasi dan alat evaluasi.

Tahap pelaksanaan diawali pendahuluan/membuka pelajaran dilanjutkan pada inti pembelajaran. Pada kegiatan penutup/ kegiatan akhir pembelajaran siswa beserta guru melakukan refleksi terhadap seluruh proses pembelajaran dan membuat resume/ kesimpulan.

Pada tahap pengamatan, pengamatan dilakukan oleh observer dengan menggunakan lembar observasi yang telah dibuat oleh penulis. Adapun hal yang diamati meliputi proses pembelajaran membuat poster melalui pendekatan keterampilan proses berbasis android yang dilaksanakan oleh penulis. Aktivitas pembelajaran menggambar poster melalui pendekatan keterampilan proses berbasis android yang dilakukan 
oleh siswa. Hasil belajar siswa pada pembelajaran membuat poster melalui pendekatan keterampilan proses berbasis android.

Pada tahap refleksi, penulis mempelajari, menganalisa, mengevaluasi hasil pengamatan observer mengenai pertama proses pembelajaran menbuat poster melalui pendekatan keterampilan proses berbasis android yang dilaksanakan oleh penulis. Kedua, pengamatan observer mengenai aktivitas pembelajaran membuat poster melalui pendekatan keterampilan proses berbasis android yang dilakukan oleh siswa. Ketiga, Hasil belajar siswa pada pembelajaran membuat poster melalui pendekatan keterampilan proses berbasis android.

Pada siklus 2 dilakukan perbaikan/ penyempurnaan berdasarkan temuan pada silklus 1 baik dalam tahap perencanaan, pelaksanaan, pengamatan/ penilaian maupun refleksi. Teknik pengumpulan data yang digunakan dalam penulisan ini adalah observasi, wawancara dan penilaian proses/ hasil.

\section{Hasil dan Pembahasan}

Pendekatan keterampilan proses berbasis android dirancang penulis untuk digunakan di kelas VIII semester 4 dalam pembelajaran seni budaya (seni rupa) pada KD 3.3. memahami konsep, syarat, alat dan bahan posterdan KD 4.3 Membuat poster. Pelaksanaan pembelajaran membuat poster dengan strategi ini dilaksanakan pada pertemuan ke 8 dan 9 ( $2 \times$ pertemuan/ $2 \times 3$ jam pelajaran/ $2 \times$ ( $3 \times 40$ menit).

\section{Pertemuan ke 8 (Senin, 18 Februari 2019)}

\section{a) Persiapan}

Beberapa hari sebelum proses pembelajara membuat poster dengan menggunakan pendekatan keterampilan proses berbasis android dilaksanakan, penulis telah menyiapkan RPP perbaikan, menyiapkan materi dan presentasi, menyiapkan media pembelajaran, alat penunjang pembelajaran dan administrasilainnya yang diperlukan. 


\section{b) Kegiatan Awal Pembalajaran}

Kegiatan pembelajaran membuat poster di kelas VIII G diawali dengan salam dan doa serta pengkondisian kelas dengan cara menyiapkan/ menertibkan siswa untuk belajar. Upaya penulis untuk menggiring siswa ke dalam proses pembelajaran adalah dengan cara melakukan apersepsi dengan memberikan beberapa pertanyaan kepada siswa tentang poster dan mengaitkannya pada materi sebelumnya yatiu gambar ilustrasi. Beberapa siswa diminta untuk menanggapi tentang poster. Pada kegiatan awal pembelajaran ini, penulis memotivasi para siswa dengan memberi contoh insfiratif tentang seseorang yang pandai/ terampil mendesain poster menjadi pengusaha poster yang sukses. Tujuannya adalah agar siswa memiliki ketertarikan akan materi pembelajaran yang akan dipelajari. Selanjutnya penulis menyampaikan $\mathrm{KD}$, tujuan pembelajaran, jenis penilaian serta Kriteria Belajar Minimal $(\mathrm{KBM})$, sehingga siswa mengetahui dengan jelas kompetensi yang harus dikuasainya, tujuan yang harus dicapai, menyiapkan diri untuk penilaian serta memiliki target belajar.

c) Kegiatan Inti Pelajaran

1) Mengamati

Siswa dipersilahkan membuka buku seni budaya untuk melihat contoh poster atau browsing internet, kemudian diamati (literasi, rasa ingin tahu,keja keras)

\section{2) Menanya}

Guru menstimulus siswa agar bertanya melalui presentasi Power Point tentang konsep, syarat, bahan, alat, serta langkah-langkah membuat poster menggunakan TI.

3) Mengumpulkan Imformasi

Siswa membaca buku siswa (seni budaya) secara cerrmat/ browsing untuk memperoleh pemahaman tentang konsep, syarat, bahan alat membuat poster. 


\section{4) Mencipta}

Langkah pertama, membuat grup WA Sbk8G, dengan tujuan untuk mempermudah penyampaian imformasi dan pengumpulan tugas. Langkah kedua, membagi siswa menjadi 8 kelompok berdasarkan urutan daftar nama siswa VIII G, masing-masing kelompok telah ditentukan topik posternya, yaitu kelompok 1 (religius), 2 (jujur), 3 (peduli sosial), 4 (peduli lingkungan), 5 (gemar membaca), 6 (cinta tanah air), 7 (kreatif), 8 (disiplin). Topik/ tujuan poster merupakan Penguatan Pndidikan Karakter/PPK). Langkah ketiga, tiap anggota dari masing-masing kelompok, membuat poster dengan judul berbeda, namun masih dalam satu topik kelompoknya. Langkah keempat, siswa menggunakan foto selfienya sebagai subjek posternya (inovatif, antusias). Langkah kelima, siswa membuat poster menggunakan HP android, dengan cara mengedit foto selfienya menggunakan aplikasi edit foto canva/ inshot/ picsart, dsb. Langkahnya adalah klik ikon aplikasi editfoto yang dipilih/ yang terdapat di HP android, pilih foto selfie yang akan di edit, tambahkan kalimat singkat dan menarik sesuai judul dengan cara diketik, klik tool yang diperlukan untuk memperindah poster dengan mempehatikan unsur-unsur seni rupa (titik, garis, bidang, bentuk, tekstur, gelap terang, warna) dan prinsip-prinsip seni rupa (keseimbangan, proporsi, komposisi, irama, kesatuan, pusat perhatian)(Teknologi Imformatika bebasis Android).

Langkah keenam, jika siswa tidak memiliki/ membawa HP, teman satu kelompoknya membantu/ meminjamkan HP-nya/ bergantian (peduli / sosial). Begitu juga jika ada siswa yang belum memahamipengoperasian aplikasi edit foto, teman satu kelompoknya membantu/sharring/berbagi ilmu, terlebih lagi jika ada siswa yang belum memiliki aplikasi edit foto, teman satu kelompoknya membantu untuk menginstal terlebih dahulu 
darigoogle play. Pada tahap ini penulis berkeliling kepada tiap kelompok untuk melihat proses pembuatan poster, menanyakan kepada setiap keompok jika ada kesulitan, memberi pengarahan serta melakukan penilaian proses.

\section{5) Mengkomunikasikan}

Pada tahap ini siswa perwakilan dari tiap kelompok mempresentasikan posternya yang telah dikirimkan via WA Sbk8G. Presentasi siswa berupa penjelasan tentang tahapan proses pembuatan poster serta penjelasan mengenai topik/ tujuan dan judul poster. Siswa mempresentasikan menggunakan laptop dan proyektor. Siswa lainnya mengapresiasi dengan cara memberikan komentar dan masukan untuk perbaikan karya.

Poster siswa yang telah dikirim/ dikumpulkan via WA Sbk8G dan dipresentasikan kemudian diprint outdan dipamerkan di kelas untuk diapresiasi bersama. Pada tahap ini penulis melakukan konfirmasi, mengomentari hasil karya siswa berdasarkan prinsip, syarat, alat dan bahan dengan memperhatikan unsur dan prinsip seni rupa sekaligus melakukan penilaian hasil/produk.

\section{d) Kegiatan Akhir Pembelajaran/ Penutup}

Pada akhir pembalajaran penulis bersama siswa melakukan refleksi, membuat kesimpulan dan menutup pembelajaran dengan doa

\section{e) Tindak lanjut}

Hasil belajar siswa pada pembelajaran membuat poster memjadi dasar untuk melakukan tindak lanjut pemblajaran (remedial/ pengayaan) dan menjadi masukan untuk perbaikan pembelajaran selanjutnya.

Berdasarkan data hasil aplikasi praktis, gambaran peningkatan proses pembelajaran di kelas VIII G SMPN 3 Tasikmalaya Jawa Barat dalam pembelajaran membuat poster menggunakan pendekatan keterampilan proses berbasis android 
pada pra tindakan, siklus 1 dan siklus 2 dapat digambarkan dengan grafik 1 di bawah ini.

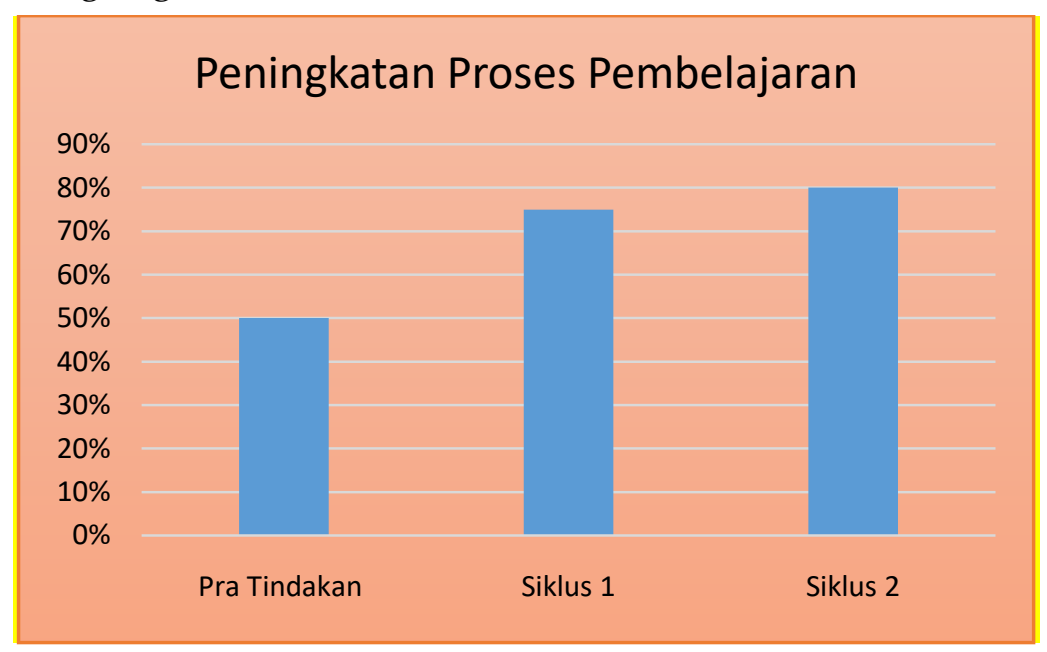

Grafik 1

Gambaran Peningkatan Proses Pembelajaran Membuat Poster Menggunakan Pendekatan Keterampilan Proses Berbasis Android (Pada Pratindakan, Siklus 1 dan Siklus 2)

Grafik diatas menunjukan bahwa proses pembelajaran membuat poster di kelas VIII G SMPN 3 Tasikmalaya Jawa Barat melalui pendekatan keterampilan proses berbasis android menggambarkan peningkatan. Peningkatan proses terjadi diantaranya disebabkan adanya perbaikan di siklus 1 pada tahap persiapan pembelajaran berupa perbaikan RPP dan kembali terjadi peningkatan pada siklus 2 karena RPPnya diperbaiki kembali/disempurnakan. Kemudian pada pelaksanaan pembelajaran adanya perbaikan pada inti pembelajaran fase menanya di siklus 1 dan disempurnakan pada siklus 2 .

Gambaran peningkatan aktivitas siswa pada pembelajaran membuat poster melalui pendekatan keterampilan proses berbasis android di kelas VIII G SMPN 3 Tasikmalaya Jawa Barat pada pra tindakan, siklus 1 dan siklus 2, gambaran peningkatan aktivitas siswa dalam proses pembelajaran dapat digambarkan dalam grafik 2 berikut. 


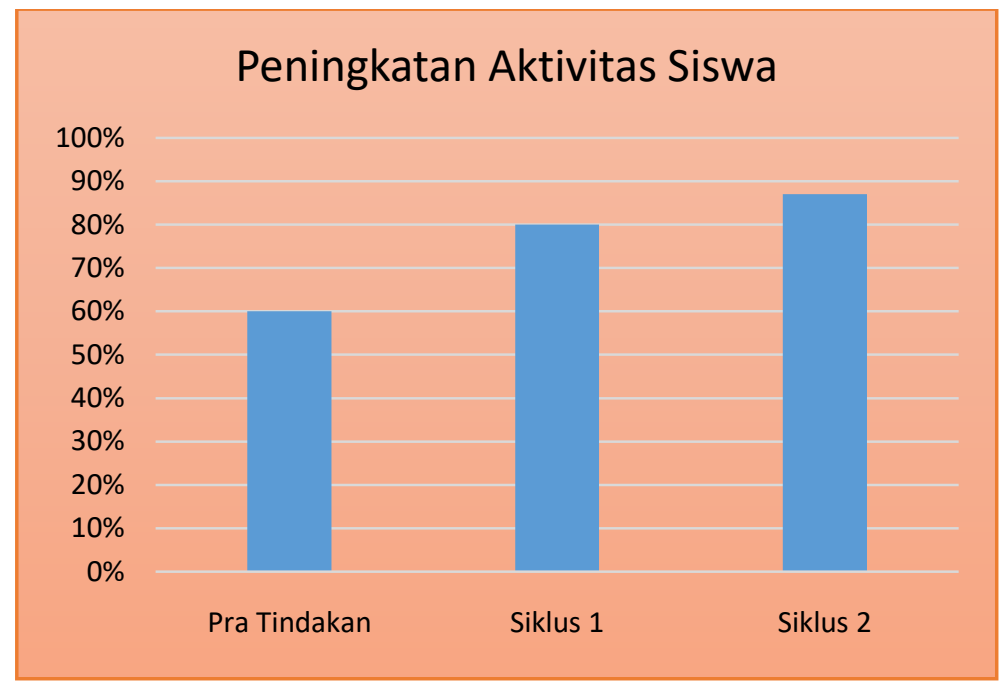

Grafik 2

Gambaran Peningkatan Aktivitas Siswa pada Pembelajaran Membuat Poster Melalui Pendekatan Keterampilan Proses Berbasis Android

Grafik di atas menggambarkan bahwa aktivitas siswa kelas VIII G SMPN 3 Tasikmalaya dalam proses pembelajaran membuat poster dengan menggunakan pendekatan keterampilan proses berbasis android menunjukan peningkatan. Peningkatan aktivitas siswa di siklus 1 terlihat mulai dari kegiatan awal, kegiatan inti sampai pada kegiatan akhir pembelajaran. Pada siklus 2 aktivitas siswa meningkat kembali terutama pada kegiatan inti pembelajaran. Hal ini terjadi karena pendekatan pembelajaran yang digunakan sesuai dengan KD, kekinian, sesuai dengan minat siswa sehingga siswa berperan aktif dalam pembelajaran.

Gambaran peningkatan hasil belajar siswa pada pembelajaran membuat poster melalui pendekatan keterampilan proses berbasis android di kelas VIII G SMPN 3 Tasikmalaya Jawa Barat pada pratindakan, siklus 1 dan siklus 2 gambaran peningkatan hasil belajar siswa dapat digambarkan dalam grafik 3 . berikut. 


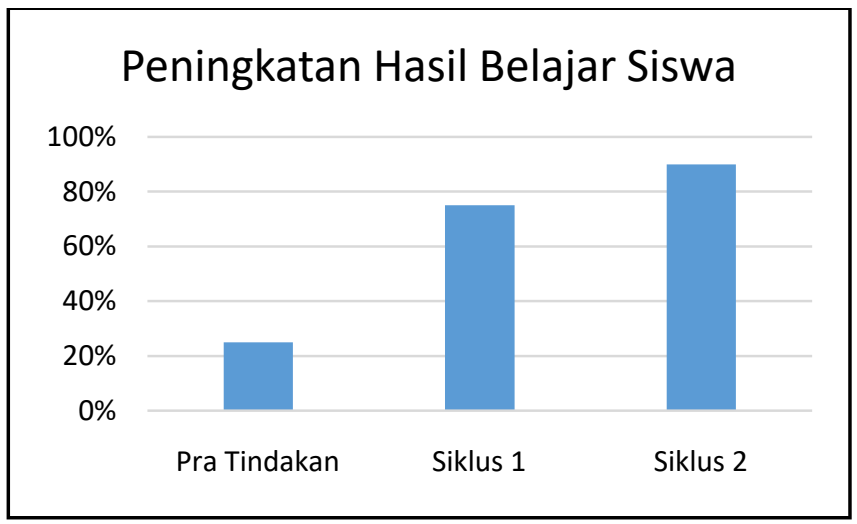

Grafik 3

Gambaran Peningkatan Hasil Belajar Siswa pada pembelajaran Membuat Poster melalui Pendekatan Keterampilan Proses berbasis Android

Grafik di atas menggambarkan bahwa hasil belajar siswa kelas VIII G SMPN 3 Tasikmalaya Jawa Barat pada pembelajaran membuat poster dengan menggunakan melalui pendekatan keterampilan proses berbasis android mengalami peningkatan. Melalui pendekatan ini terbukti telah terjadi peningkatan pada hasil belajar siswa ditandai dengan meningkatnya pencapaian hasil belajar siswa dari rata-rata 82 (25\%) pada pra tindakan menjadi 85 (75\%) pada siklus 1 (meningkat 50\%) dan semakin meningkat pada siklus 2 menjadi 88 (90\%). Dengan demikian berdasarkan analisis aplikasi praktis dapat disimpulkan bahwa pendekatan keterampilan proses berbasis android dapat meningkatkan proses pembelajaran, aktivitas siswa dalam pembelajaran dan hasil belajar siswa pada pembelajaran membuat poster.

\section{Penutup}

Berdasarkan hasil penelitian dapat disimpulkan bahwa penerapan pendekatan keterampilan proses berbasis android dapat meningkatkan hasil belajar siswa pada pembelajaran membuat poster yang ditandai dengan meningkatnya proses pembelajaran siswa dari rata-rata skore 2 (50\%) kategori cukup pada pratindakan, menjadi 3 (75\%) kategori baik 
pada siklus 1 (meningkat 25\%), dan semakin meningkat pada siklus 2 menjadi 3,2 (80\%) dengan katagori amat baik (meningkat 5\%). Kedua, meningkatnya aktivitas pembelajaran siswa dari rata-rata skor $3(60 \%)$ katagori cukup pada pra tindakan, menjadi 4 (80\%) katagori tinggi pada siklus 1 (meningkat 20\%) dan semakin meningkat pada siklus 2 dengan peningkatan rata-rata skor menjadi $4,4(87 \%)$ katagori sangat tinggi (meningkat $7 \%$ ). Ketiga, meningkatnya hasil belajar siswa rata-rata 82 (25\%) pada pra tindakan menjadi $85(75 \%)$ pada siklus 1 (meningkat 50\%) dan semakin meningkat pada siklus 2 menjadi 88 (90\%). Berdasarkan analisis aplikasi praktis dapat disimpulkan bahwa pendekatan keterampilan proses berbasis android dapat meningkatkan hasil belajar siswa pada pembelajaran membuat poster.

\section{Ucapan Terima Kasih}

Terima kasih saya sampaikankepada Bapak Kepala Dinas, Bapak Pengawas, dan khususnya Bapak Kepala Sekolah SMP Negeri 3 Tasikmalaya yang telah memberikan kesempatan dan fasilitas sehingga penelitian PTK ini dapat dilakukan dengan baik. Disamping itu, terima kasih disampaikan pula kepada teman-teman guru di SMP Negeri 3 Tasikmalaya yang telah membantu terlaksananya penelitian dan terselesaikannya penulisan artikel ini.

\section{Daftar Referensi}

Kuana, Khuanai. (2017). Impressive Learning Strategies With Indoctrinating Research Based to Creative Thinking Skills for Educational Students. European Journal of Education Studies. 3,286304.DOI: 10.5281 /zenodo.260008.

Permendikbud No. 22 Tahun 2016 tentang Standar Proses Pendidikan Dasar dan Menengah.

Purnomo, dkk. (2017). Seni Budaya Kelas VIII SMP/MTs. Jakarta: Kemdikbud. 
Pusat Bahasa Departemen Pendidikan Nasional. (2005). Kamus Besar Bahasa Indonsia Cetakan Ketiga.Jakarta: Balai Pustaka.

Raba, A. (2017). The Infact of Effective Teaching strategies on Producing Fast and Good Learning Outcomes. International Journal of Research. 5,43-58.DOI: 10.5281/zenodo.259563.

http://www.dosenpendidikan.com, diunduh 24 April 2019

http://eprints.uny.ac.id.,diunduh 24 Aprii 2019

https://www.rijal09.com/2016/04/pengertianpendekatan-prosespendekatan.html., diunduh 10 Desember 2019 